Ann. Biol. anim. Bioch. Biophys., 1978, 18 (4), 831-836.

\title{
Neuroanatomical substrates of reproductive behavior in male sunfish (Genus Lepomis)
}

\author{
par L. S. DEMSKI
}

School of Biological Sciences, Thomas Hunt Morgan Building, University of Kentucky, Lexington, Kentucky 40506, USA.

\begin{abstract}
Summary. Electrical stimulation of the brain has been carried out in both free-swimming (chronic preparation) and anesthetized (acute preparation) sunfish. Nestbuilding has been evoked from the area dorsalis telencephali pars centralis (ADTPC) of the telencephalic lobe. This response has also been triggered by stimulation in the preoptic area (POA), as has courtship circling, spawning maneuvers and sperm release in chronic preparations and sperm release in acute preparations. The latter response has been elicited in acute preparations by stimulation of a locus of points extending from the POA, through the lateral hypothalamus, lateral tegmentum of the midbrain, basal medulla and initial portion of the spinal cord. The primary motor neurons controlling sperm release are located in the rostral spinal cord since the response was triggered by stimulation of an isolated segment in this area. Recent autoradiographic studies using $\mathrm{H}^{3}$-testosterone have demonstrated that the parvocellular region of the preoptic area and parts of both the tuberal nuclear complex and anterior pituitary contain testosterone-concentrating neurons. It is suggested that androgens may influence the sperm release system and perhaps other reproductive mechanisms via some of these specialized cells. This is consistent with findings that certain reproductive responses in male sunfish are androgen dependent. $A$ fentative model of some aspects of the neural control of reproductive behavior in male sunfish can be suggested. The ADTPC mediates its effects by influencing the POA.This idea is supported by electrophysiological experiments. The POA is involved in the integration of hormonal, olfactory and probably other information relevant to reproductive behavior. It influences sexual activities through systems such as the one described for sperm release.
\end{abstract}

\section{Introduction.}

Relatively little is known of the neural mechanisms controlling reproductive behavior in fishes. In response to this lack of information, our laboratory has been engaged in a series of experiments concerned with the anatomical mapping of brain areas involved in male sexual responses in North American sunfish (genus Lepomis). Two general methods have been used. The first consists of electrical stimulation of small areas of the brain in free-swimming (Demski and Knigge, 1971) as well as anesthetized, partially immobilized animals (Demski ef al., 1975). The second method consists of autoradiography using labeled testosterone to identify and map androgenconcentrating neurons in the fish brain (Pfaff, Morrell, Kelley and Demski, in prepara- 
tion). The purpose of this paper is to review our results and assimilate these data into a working hypothesis concerning the neural pathways and mechanisms controlling male sexual behavior in sunfish.

\section{Materials and methods.}

\section{Electrical stimulation of the brain.}

Details of the techniques for implantation and testing of stimulation electrodes in free-swimming sunfish have been previously published (Demski and Knigge, 1971 ; Demski and Picker, 1973). One of the drawbacks of this method is the limitation on the number of brain sites that can be tested in each animal. Anatomical mapping can be greatly facilitated if studies can be carried out in fishes with their heads immobilized such that the cranial cavity can be opened and held above the surface of the water in which the rest of the animal is immersed. With this preparation many electrode tracks can be run in each fish by using a standard micromanipulator to advance the electrode. The major drawback of this preparation is that the test animal, which in our procedure is anesthetized, can not perform the normal sequences of reproductive behavior. However, the finding that sperm release could be elicited under these conditions permitted a thorough mapping of the major areas of the brain from which at least part of the male reproductive sequence can be evoked. This method also allows the lowest threshold point along each electrode track to be identified and marked for histological verification. Futher details of this procedure are beyond the scope of this paper (see Demski et al., 1975).

\section{Autoradiography.}

The following procedures were carried out in collaboration with Drs. Pfaff, Morrell and Kelley at Rockefeller University. Methodological details are essentially the same as reported by Pfaff and Keiner (1973). Six mature male green sunfish (Lepomis cyanellus) were surgically castrated, and within $72 \mathrm{hrs}$, four of them were given intraperitoneal injections of tritiated-testoterone $(200 \mathrm{Ci} / 100 \mathrm{~g}$ body weight). All fish (four experimentals and two controls) were sacrificed between 1 to 3 hrs following the injection time and their brains removed and frozen using dry ice. Tissue was blocked and sectioned on a freezing microtome. Parasagittal and transverse sections were placed on glass slides, coated with Kodak NTB-3 nuclear emulsion and placed in the dark for a period up to 14 months. Slides were developed and counterstained with cresyl violet. Only cells with grain counts of at least five times the mean background level (an adjacent cell-sized area of neuropil) were considered as labeled. Areas with labeled cells were plotted on a series of representative sections (fig. 1).

\section{Results and conclusions.}

Several reproductive patterns have been elicited by electrical stimulation of the brain in unanesthetized, free-swimming sunfish. Sweeping or nestbuilding has been evoked in bluegills (Lepomis macrochirus) of both sexes (Demski and Knigge, 1971). 

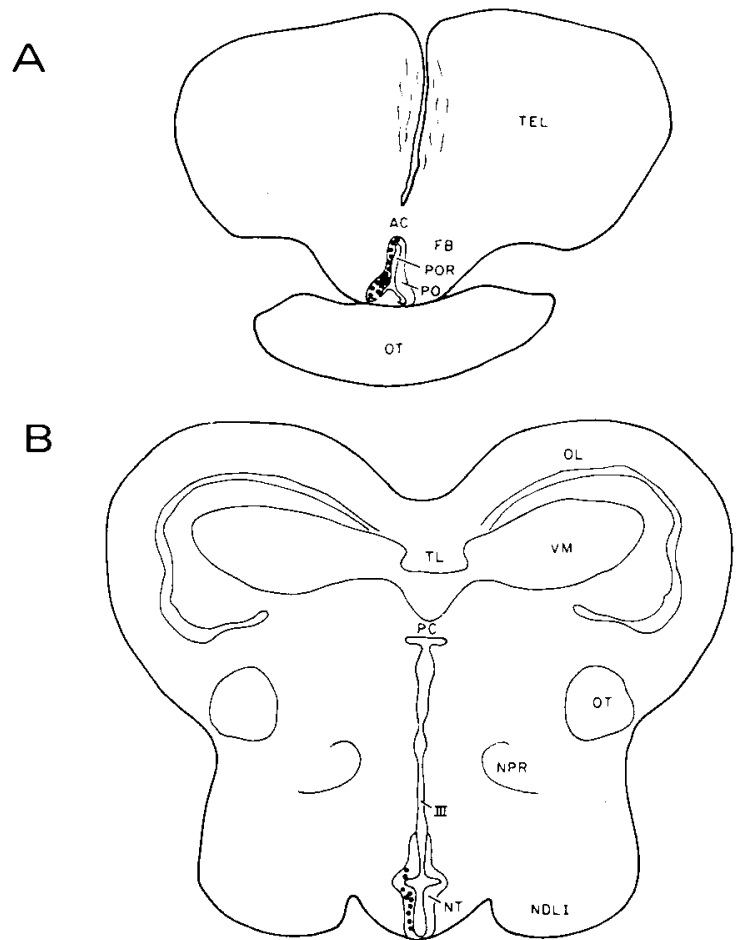

FIG. 1. - A) Transverse section through the brain (telencephalon) of the green sunfish, Lepomis cyanellus showing labelled cells in the preoptic area following injection of $\mathrm{H}^{3}$-festosterone. The left side of the figure shows the precise positions of labelled cells in this section, each black dot indicating one labelled cell. The right side of the figure shows anatomical structures indicated with abbreviations. Nomenclature is from Demski ef al., 1975.

B) Transverse section through the diencephalon of the green sunfish, at the level of the anterior portion of nucleus fuberalis, showing testosterone-concentrating cells in nucleus fuberalis. Conventions as for section $A$ of this figure. AC, anterior commissure ; FB, forebrain bundles; NDLI, nucleus diffusus lobi inferiors; NPR, nucleus prerotundus ; NT, nucleus tuberalis ; OL, optic lobe ; OT, optic tract; PC, posterior commissure ; PO, preoptic area ; POR, preoptic recess of third ventricle ; TEL, telencephalon ; TH, thalamus ; TL, torus longitudinalis ; VM, ventricle of the midbrain ; III, third ventricle.

Nestbuilding in sunfish appears to be androgen dependent (Smith, $1969 ; 1970$ ). This may be the reason that under natural conditions only males have been observed to perform this activity (Miller, 1963). Sweeping responses have resulted from stimulation in the area dorsalis telencephali pars centralis (ADTPC) and the preoptic area (POA) in several bluegills (Demski and Knigge, 1971 ; Bauer and Demski, in preparation). An interesting feature of this response is that it was evoked most readily by low frequency stimulation $(2-10 \mathrm{~Hz})$. This may be correlated with neurophysiological findings that similar frequencies of telencephalic lobe stimulation are most effective in triggering repetitive discharges from parvocellular neurons in the sunfish POA (Hallowitz ef al., 1971). It can be suggested that the low frequency telence- 
phalic stimulation in free-swimming sunfish results in nestbuilding by selectively activating the POA and that stimulation in the POA results in sweeping through direct activation of the same units.

Courtship, defined as circling another fish with attempts to lead it toward a nesting area, has only been evoked by stimulation of the POA in mature males including both bluegills (Demski and Knigge, 1971) and green sunfish (Demski, unpublished observafions). One of the green sunfish was stimulated in the presence of a preserved female, held on a wire and maneuvered by the experimenter. The test animal not only approached, circled and attempted to lead the stimulus fish but also tried to spawn, i.e. placed its ventral aspect against the dead female and released semen.

As mentioned above, the use of anesthetized-immobilized animals can greatly facilitate brain mapping. In a series of pilot experiments using anesthetized green sunfish, it was determined that stimulus bound semen discharge with active spermatozoa could be evoked from brain sites ranging from the POA to the spinal cord. Later more detailed mapping studies (Demski ef al., 1975) revealed that the lowest threshold sperm release sites formed a locus running from the POA through the dorsal hypothalamus, lateral tegmentum of the midbrain' basal medulla and rostral spinal cord.

Combined stimulation-ablation experiments indicated that sperm release could be evoked by stimulation of a small isolated segment of rostral spinal cord and thus, that the lower motor system controlling the response originated at this level (see details in Demski et al., 1975). Recent experiments have demonstrated that sperm release responses can also be evoked by brain stimulation in bluegills (Baver and Demski, in preparation).

With regard to autoradiographic mapping, brains from four experimental green sunfish have been studied (Pfaff, Morrell, Kelley and Demski, in preparation). So far, testosterone-concentrating neurons have been located in the POA (parvocellular neurons only), the tuberal nuclear complex and specific segments of the anterior pituitary (fig. 1). The androgen-concentrating cells in the POA are found in the same region from which sperm release and courtship have been electrically evoked in green sunfish (Demski et al., 1975). Testosterone uptake by the tuberal area and pituitary most likely relates to feedback mechanisms controlling gonadotropin release (Peter, 1970 ; 1973). Testosterone-concentrating neurons were not found in other areas of the sunfish brain, including the ADTPC and the midbrain and medullary portions of the sperm release system.

The following tentative model of the neural control of reproductive behavior in male sunfish is put forward in an attempt to assimilate and summarize the results discussed above. Telencephalic lobe areas (especially the ADTPC) seem to be involved in nestbuilding and perhaps other aspects of reproductive behavior in male sunfish. These areas probably are not directly affected by androgenic hormones. Based on electrophysiological evidence, higher forebrain influences on reproductive behavior may well be mediated by activation of small neurons in the POA. The POA is the only region from which more than one reproductive response has been electrically evoked and thus seems to be an important area for the control of sexual behavior in sunfish. Some of its small neurons concentrate testosterone and presumably their electrical activity is influenced by variations in circulating androgen levels. This may be one 
of the key factors regulating seasonal breeding activities. Small preoptic neurons in sunfish may also be influenced by olfactory stimuli since they can readily be activated by olfactory tract stimulation (Hallowitz et al., 1971). This observation gains special importance in light of evidence that male sunfish may use olfactory cues in setting up nesting colonies (Gerald, 1970). Thus, the POA may be involved in the integration of hormonal, olfactory and probably other types of information relevant to reproductive behavior. On the output side, the POA appears to have functional connections that permit artificial electrical activation of complex behavioral sequences such as courtship as well as more elemental patterns like sperm release. It seems reasonable to suggest that under natural conditions the POA influences reproductive behavior, at least in part, through systems such as the one proposed for sperm release.

Symposium sur la Reproduction des Poissons Paimpont, France, 19-21 septembre 1977.

Acknowledgments. - I wish to thank Diana $\mathrm{H}$. Baver for providing excellent technical - assistance in many of the studies discussed in this paper and for the use of her unpublished data. Support was provided by National Science Foundation Grant BNS7618617 and funds from the University of Kentucky Research Foundation.

Résumé. La stimulation électrique du cerveau a été pratiquée sur des poissons (gen. Lepomis) nageant librement et sur des poissons anesthésiés et immobilisés. La stimulation de l'area dorsalis telencephali pars centralis (ADTPC) du lobe télencéphalique a stimulé la nidification. Cette réaction, ainsi que plusieurs phases du frai et la libération de spermatozoïdes, a également été déclenchée par la stimulation de l'aire préoptique (POA) chez les poissons non anesthésiés, nageant librement. Chez les poissons anesthésiés ef immobilisés, la libération de spermatozoïdes a été obtenue par la stimulation d'un ensemble de points allant du POA à travers l'hypothalamus latéral, le tegmentum latéral du mésencéphale, la medulla ventrale et la partie supérieure de la moelle épinière. Les neurones moteurs primaires qui contrôlent la libération des spermatozoïdes sont siłués dans la moelle épinière rostrale puisque la réaction a été obtenue par la stimulation d'un segment isolé de cette région.

Des études radioautographiques récentes avec $\mathrm{H}^{3}$-testostérone ont démontré que la région préoptique parvocellulaire ainsi qu'une partie du nucleus tuberalis et du lobe antérieur de l'hypophyse contiennent des neurones qui concentrent de la testostérone. Ceci semble indiquer que les hormones androgènes peuvent influencer le système de la libération de spermatozoïdes et peut-être d'autres mécanismes de reproduction via certaines de ces cellules spécialisées. Ceci est en accord avec les résultats établissant que certaines réactions de reproduction chez les poissons mâles dépendent des hormones androgènes. On peut suggérer un modèle préliminaire de certains aspects du contrôle neural du comportement reproductif chez les poissons (gen. Lepomis). L'ADTPC agit en influençant la POA. Ceci est appuyé par des expériences électrophysiologiques. La POA est impliquée dans l'intégration d'information hormonale, olfactive et probablement autre, liée au comportement de reproduction. Elle influence les activités sexuelles par des systèmes tels que celui décrit pour la libération des spermatozoïdes.

\section{References}

DEMSKI L. S., BAUER D. H., GERALD J. W., 1975. Sperm release evoked by electrical stimulation of the fish brain : a functional-anatomical study. J. exp. Zool., 191, 215-232.

DEMSKI L. S., KNIGGE K. M., 1971. The telencephalon and hypothalamus of the bluegill (Lepomis macrochirus) : evoked feeding, aggressive and reproductive behavior with representative frontal sections. J. comp. Neurol., 143, 1-16. 
DEMSKI L. S., PICKER L. F., 1973. A moveable electrode for brain stimulation in fishes. Comp. Biochem. Physiol., 44A, 457-460.

GERALD J. W., 1970. Species isolating mechani sms in genus Lepomis. Ph. D. Dissertation, Univ. of Texas at Austin.

HALLOWITZ R. A., WOODWARD D. J., DEMSKI L. S., 1971. Forebrain activation of single units in preoptic area of sunfish. Comp. Biochem. Physiol., 40A, 733-741.

MILLER H. C., 1963. The behavior of the pumpkinseed sunfish, Lepomis gibbosus (Linneaus), with notes on the behavior of other species of Lepomis and the pigmy sunfish, Elossoma evergladei. Behaviour, 22, 88-151.

PETER R. E., 1970. Hypothalamic control of thyroid gland activity and gonadal activity in the goldfish, Carassius auratus. Gen. comp. Endocrinol., 14, 334-356.

PETER R. E., 1973. Neuroendocrinology of teleosts. Amer. Zool., 13, 743-755.

PFAFF D. W., KEINER M., 1973. Atlas of estradiol-concentrating cells in the central nervous system of the female rat. J. comp. Neurol., 151, 121-158.

SMITH R. J. F., 1969. Control of prespawning behavior of sunfish (Lepomis gibbosus and L. megalotis). I. Gonadal androgen. Anim. Behav., 17, 279-285.

SMITH R. J. F., 1970. Control of prespawning behavior of sunfish (Lepomis gibbosus and L. megalotis). II. Environmental factors. Anim. Behav., 18, 575-587. 